\title{
Dopaminergic D4 receptor polymorphism among 24 populations of India: an anthropological insight
}

\author{
Kallur Nava SARASWATHY ${ }^{1 *}$, Sanjenbam Yaiphaba MEITEI ${ }^{2 \dagger}$, Huidrom Suraj SINGH ${ }^{1 \dagger \dagger}$, \\ Antoneta Teresa JOSEPH ${ }^{3}$, Prakash Ranjan MONDAL ${ }^{1}$, Benrithung MURRY ${ }^{1}$, \\ Mohinder Pal SACHDEVA ${ }^{1}$, Pradeep Kumar GHOSH ${ }^{1}$ \\ ${ }^{1}$ Molecular Anthropology Laboratory, Department of Anthropology, University of Delhi, Delhi 110007, India \\ ${ }^{2}$ Department of Anthropology, Vidyasagar University, Midnapore, West Bengal 721102, India \\ ${ }^{3}$ University of Sheffield, Sheffield Business Park, Europa Link, Sheffield S9 1XU, UK
}

Received 2 April 2013; accepted 9 June 2013

\begin{abstract}
Various studies have tried to elucidate the genomics underlying the ethnic diversity of Indian populations. The 48-basepair variable number tandem repeat (VNTR) of the DRD4 gene, besides its clinical importance, has been a subject of interest for understanding human evolutionary history worldwide. In spite of its highly polymorphic nature it has not been much explored by anthropologists, especially in the Indian context. In the present study, an attempt was made to infer the allelic variation of the repeat allele among 24 Indian ethnic groups belonging to different ethnic and linguistic groups along with different geographic affiliations. Only the $2 \mathrm{R}, 3 \mathrm{R}, 4 \mathrm{R}, 5 \mathrm{R}, 6 \mathrm{R}$, and $7 \mathrm{R}$ repeat alleles were found in the studied populations, with $4 \mathrm{R}$ being the most frequent followed by $2 \mathrm{R}$. All the other repeat alleles $(3 R, 5 R, 6 R$, and $7 R$ ) occurred at very low frequency. Based on the $4 R$ and $5 R$ frequencies, the study reveals a common genetic substratum of the Indian population as already proposed by earlier studies. Further, the study also highlights the inflow of genes from the north.
\end{abstract}

Key words: $D R D 4$ gene, linguistics, tribe, caste, common genetic substratum

\section{Introduction}

India, with its wide range of climatic and environmental conditions and huge diversity in terms of language, culture, religion and ethnicity, must, like Africa, have played an important role in human evolutionary history. Evidence of fossilized Hominoidae (Pongidae and Protohominidae) of late Miocene period, such as Gigantopithecus, Brahmapithecus, Ramapithecus, Sivapithecus from Siwaliks and Homo erectus from the Narmada basin of India, hints towards the role of the subcontinent in the origin of human species (Pilbeam, 1979; Benefit and McCrossin, 1995; Ruvolo, 1997; Trinkaus, 2005). This can be further supported by a recent report by Saraswathy et al. (2010), which proposed a common genetic substratum of India. To understand the peopling of India, and in turn the peopling of the world, researchers have used several genetic markers. Markers related to the dopaminergic system, specifically dopamine D4

* Correspondence to: Kallur Nava Saraswathy, Department of Anthropology, University of Delhi, Delhi 110007, India.

E-mail: knsaraswathy@yahoo.com

${ }^{\dagger}$ Present address: Sanjenbam Yaiphaba Meitei, Department of Anthropology, Manipur University, Canchipur (Imphal), Manipur 795003, India.

$\dagger$ Present address: Huidrom Suraj Singh, Department of Anthropology and Tribal Development, Guru Ghasidas Vishwavidayalaya, Bilaspur, (C.G.), 495009, India.

Published online 25 July 2013

in J-STAGE (www.jstage.jst.go.jp) DOI: 10.1537/ase.130609 receptor (DRD4), are now proving to be an effective tool for diversity studies. $D R D 4$ polymorphism is being extensively used to understand micro- and macro-migration, specifically for two reasons: (i) its highly polymorphic nature; and (ii) the simple technology involved in typing this gene polymorphism. The polymorphism of $D R D 4$ is revealed in the variable number of imperfect 48-basepair (bp) tandem repeats on exon 3, ranging from 2 to 11 repeat (R) units. The 4, 7 and 2 repeats are the most common ones (Chen et al., 1999).

$D R D 4$ repeat alleles are reported to be implicated in various neuropsychiatric disorders/traits, such as novelty seeking (Malhotra et al., 1996; Jonsson et al., 1997; Gelernter et al., 1997; Sullivan et al., 1998; Ray et al., 2009), attention deficit hyperactivity disorder (ADHD) (LaHoste et al., 1996; Swanson et al., 1998; Swanson and Moyzis, 2003; Grady et al., 2003), and risk behaviors such as addiction and gambling (Comings et al., 1999; McGeary, 2009; Eisenegger et al., 2010). Apart from its clinical implications, $D R D 4$ offers possibilities for use in anthropological studies due its great variation among the world's populations (Chang et al., 1996).

Chen et al. (1999) also proposed that long repeat alleles of the DRD4 gene (5-11 repeats) were associated with longdistance migrations. Only a few anthropological studies on $D R D 4$ polymorphism in India are available: just three papers have been published in which DRD4 polymorphism was screened in Indian populations (Khurana and Seshadri, 2003; Ghosh and Seshadri, 2005; Bhaduri et al., 2007). Further, the populations studied in these publications were also not ethnically well defined; they were rather essentially 
geographically defined populations. Thus, in the present study an attempt is made to understand human evolutionary history of India with respect to $D R D 4$ repeat polymorphism among 24 ethnically, geographically, and linguistically welldefined populations.

\section{Materials and Methods}

\section{Sample collection}

Intravenous blood samples $(5 \mathrm{ml})$ were collected from 894 individuals belonging to 24 different Indian communities from different geographical regions (Figure 1), after obtaining prior written consent. Each community is distinguishable ethnically, linguistically, and geographically. Details of these populations are given in Table 1. The present study was approved by the Ethical Committee of the Department of Anthropology, University of Delhi, India.

\section{Data analysis}

Genomic DNA was extracted from the collected blood samples using the salting-out procedure (Miller et al., 1988). The polymerase chain reaction (PCR) of the DRD4 48-bp VNTR locus was performed using a protocol previously described by Eisenberg et al. (2008) with some modifications. The $15 \mu \mathrm{l}$ PCR reaction mixture contained $1 \times$ PCR buffer, $1.5 \mu \mathrm{M}$ forward primer (5'-GCGACTACGTGGTCTAC TCG-3'), $1.5 \mu \mathrm{M}$ reverse primer (5'-AGGACCCTCATGG CCTTG-3'), $200 \mu \mathrm{M}$ dATP, dTTP, dCTP and $100 \mu \mathrm{M}$ dITP and dGTP, $3 \%$ dimethyl sulfoxide, 1.5 units Taq DNA polymerase and 50 ng DNA template. Thermocycling conditions were: $15 \mathrm{~min}$ at $95^{\circ} \mathrm{C}$ to activate the enzyme and denature the DNA; 40 cycles of 1 min denaturation at $94^{\circ} \mathrm{C}, 1$ min annealing at $64.4^{\circ} \mathrm{C}, 1 \mathrm{~min} 30 \mathrm{~s}$ extension at $72^{\circ} \mathrm{C}$; followed by

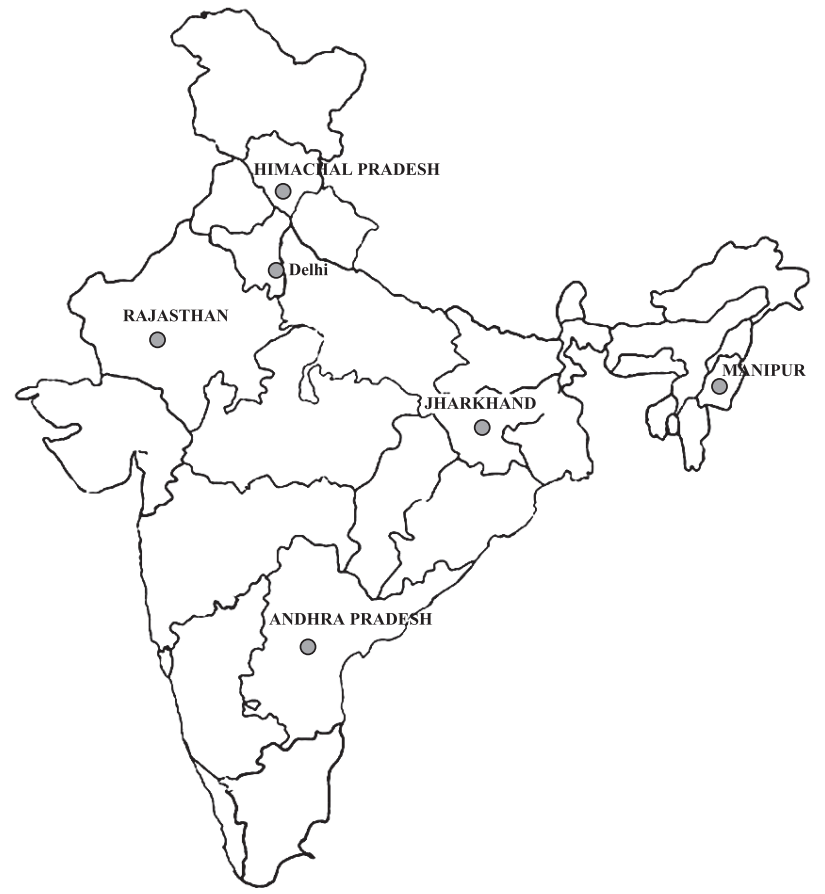

Figure 1. Outline map of India showing the geographical locations of the sampled areas of the 24 populations.

one cycle of $10 \mathrm{~min}$ final extension at $72^{\circ} \mathrm{C}$. These primers yielded a $4 \mathrm{R}$ PCR product of $475 \mathrm{bp}$. Samples were run with a 100-bp ladder stained with ethidium bromide and visualized under UV light on $2.0 \%$ agarose gel. To avoid genotyping error, the technique was first standardized on

Table 1. Name of the population, state, geographical location, category, their linguistic affiliation and number of samples analyzed

\begin{tabular}{|c|c|c|c|c|c|}
\hline State & Population & Geographical location & Category & Linguistic group & No. of samples \\
\hline Himachal & Jat & North India & Caste & Indo-European & 33 \\
\hline \multirow[t]{2}{*}{ Pradesh } & Rajput & & Caste & Indo-European & 33 \\
\hline & Brahmin & & Caste & Indo-European & 44 \\
\hline \multirow[t]{3}{*}{ Delhi } & Punjabi & North India & Caste & Indo-European & 29 \\
\hline & Sindhi & & Caste & Indo-European & 33 \\
\hline & Aggarwal & & Caste & Indo-European & 121 \\
\hline \multirow[t]{8}{*}{ Manipur } & Kabui & North-east India & Tribe & Tibeto-Burman & 37 \\
\hline & Aimol & & Tribe & Tibeto-Burman & 43 \\
\hline & Kom & & Tribe & Tibeto-Burman & 24 \\
\hline & Thadou & & Tribe & Tibeto-Burman & 37 \\
\hline & Meitei & & Non-tribe & Tibeto-Burman & 38 \\
\hline & Paite & & Tribe & Tibeto-Burman & 41 \\
\hline & Brahmin & & Caste & Tibeto-Burman & 27 \\
\hline & Muslim & & Religious group & Tibeto-Burman & 31 \\
\hline \multirow[t]{2}{*}{ Jharkhand } & Oraon & East India & Tribe & Dravidian & 29 \\
\hline & Munda & & Tribe & Austro-Asiatic & 25 \\
\hline \multirow[t]{4}{*}{ Rajasthan } & Patelia & West India & Tribe & Indo-European & 20 \\
\hline & Naikda & & Tribe & Indo-European & 22 \\
\hline & Damor & & Tribe & Indo-European & 25 \\
\hline & Kathodi & & Tribe & Indo-European & 35 \\
\hline Andhra & Brahmin & South India & Caste & Dravidian & 34 \\
\hline \multirow[t]{3}{*}{ Pradesh } & Kolam & & Tribe & Dravidian & 48 \\
\hline & Thoti & & Tribe & Dravidian & 36 \\
\hline & Nayakpod & & Tribe & Dravidian & 49 \\
\hline Total & & & & & 894 \\
\hline
\end{tabular}


polyacrylamide gel and shifted to agarose gel for convenience, only after tallying the genotyping results of around 25 samples from both the gels. Allele frequencies were calculated using the statistical tool POPGENE1.31 (Yeh and Yang, 1999). Hardy-Weinberg equilibrium was determined using the $\chi^{2}$ goodness-of-fit test.

\section{Results}

Of all the repeat polymorphic variants of DRD4 48-bp VNTR reported among the world populations, only six variants/alleles were found in the present study. The two most commonly found alleles in the studied Indian populations are the $4 \mathrm{R}$ and the $2 \mathrm{R}$ allele. These two alleles are shared by all the studied populations, while the other alleles observed, i.e. $3 R, 5 R, 6 R$, and $7 R$, were distributed to varying extents. The $2 \mathrm{R}$ allele varies from 0.02 (Oraon of east India and Kolam of south India) to 0.29 (Kom of north-east India), while the 4R allele ranges from 0.69 among Punjabis of north India to 0.94 among Manipur Muslims of north-east India. However, the $3 \mathrm{R}, 5 \mathrm{R}, 6 \mathrm{R}$, and $7 \mathrm{R}$ alleles are found to be distributed in a low frequency among the studied populations. The other higher-repeat alleles, e.g. 8R, 9R and 10R, have been reported among other world populations but none of these higher repeats is observed in the present study. The average allele frequencies of $2 \mathrm{R}, 3 \mathrm{R}, 4 \mathrm{R}, 5 \mathrm{R}, 6 \mathrm{R}$, and $7 \mathrm{R}$ are $0.138,0.007,0.827,0.010,0.011$, and 0.007 , respectively. Most of the population groups under study (15 populations) deviate from Hardy-Weinberg equilibrium (Table 2). This deviation from Hardy-Weinberg equilibrium might be due to reasons such as small sample size, small population size, consanguinity, or low frequency of the minor repeat alleles.
When the studied populations are grouped on the basis of geography, the south Indian populations have the highest frequency of $4 \mathrm{R}$ allele $(0.852)$, followed by east Indian (0.845), west Indian (0.843) north-east Indian (0.814), and north Indian populations $(0.811)$, respectively (Table 2$)$. This is in contrast to the $2 \mathrm{R}$ and $7 \mathrm{R}$ alleles, for which northeast Indian and north Indian populations, respectively, exhibit higher frequencies. The south Indian populations have the lowest frequencies of $2 \mathrm{R}$ while the $7 \mathrm{R}$ is absent.

\section{Discussion}

Proto-Australoids could be, as proposed by Guha, the original inhabitants of India (Guha, 1944). Almost all the tribes, except for those of the north-eastern region, are found to have Proto-Australoid ethnic elements, though in varying degrees. Specifically, Austro-Asiatic and Dravidianspeaking tribal groups of India are reported to be modern representatives of the earliest settlers of the subcontinent (Kumar et al., 2008), who would possibly have had the socalled Proto-Australoid ethnic elements. The evolution of the DRD4 48-bp repeat polymorphism among the human lineage is not very clear. Earlier studies on chimpanzees, gorillas, and orangutans revealed that the ancestral hominoid gene had the 5R allele (Livak et al., 1995). However, a recent study among other primate members observed the highly polymorphic nature of the repeat gene: high repeat alleles $(7,8$, and 9) are observed among spider monkeys (The DB-DRD4 Database Project: http://www.ibibiobase. com/projects/db-drd4/what_is_drd4.htm). Another hominoid ape Hylobates shows regional variation and a complex nature of sequence repeat (Inoue-Murayama et al., 2000).

Table 2. Distribution of allele frequencies of $D R D 4$ polymorphism among 24 population groups of India

\begin{tabular}{|c|c|c|c|c|c|c|c|c|c|}
\hline \multirow{2}{*}{ State } & \multirow{2}{*}{ Population } & \multicolumn{6}{|c|}{ Allele frequencies } & \multicolumn{2}{|c|}{ HWE ( $P$ value $)$} \\
\hline & & $2 \mathrm{R}$ & $3 \mathrm{R}$ & $4 \mathrm{R}$ & $5 \mathrm{R}$ & $6 \mathrm{R}$ & $7 \mathrm{R}$ & $\chi^{2}$ & $G^{2}$ \\
\hline Himachal & Jat & 0.24 & 0 & 0.76 & 0 & 0 & 0 & $0.039 *$ & 0.050 \\
\hline \multirow[t]{2}{*}{ Pradesh } & Rajput & 0.05 & 0 & 0.88 & 0.03 & 0 & 0.05 & $0.002 *$ & 0.372 \\
\hline & Brahmin & 0.07 & 0.01 & 0.86 & 0.02 & 0.03 & 0 & $0.000 *$ & $0.010^{*}$ \\
\hline \multirow[t]{3}{*}{ Delhi } & Punjabi & 0.22 & 0.02 & 0.69 & 0 & 0.04 & 0.03 & $0.000 *$ & $0.040^{*}$ \\
\hline & Sindhi & 0.06 & 0 & 0.91 & 0 & 0 & 0.03 & 0.965 & 0.919 \\
\hline & Aggarwal & 0.21 & 0.02 & 0.76 & 0 & 0.01 & 0.004 & $0.000 *$ & 0.077 \\
\hline \multirow[t]{8}{*}{ Manipur } & Kabui & 0.15 & 0.01 & 0.82 & 0.01 & 0 & 0 & 0.413 & 0.625 \\
\hline & Aimol & 0.24 & 0.01 & 0.74 & 0 & 0 & 0 & 0.203 & 0.220 \\
\hline & Kom & 0.29 & 0.00 & 0.71 & 0 & 0 & 0 & $0.039 *$ & $0.046^{*}$ \\
\hline & Thadou & 0.15 & 0.03 & 0.81 & 0.01 & 0 & 0 & 0.160 & 0.305 \\
\hline & Meitei & 0.08 & 0.00 & 0.87 & 0.01 & 0.03 & 0.01 & $0.016^{*}$ & 0.274 \\
\hline & Paite & 0.17 & 0.01 & 0.81 & 0.01 & 0 & 0 & 0.121 & 0.221 \\
\hline & Brahmins & 0.15 & 0 & 0.82 & 0 & 0 & 0.04 & $0.000 *$ & $0.016^{*}$ \\
\hline & Muslims & 0.07 & 0 & 0.94 & 0 & 0 & 0 & $0.002 *$ & $0.048 *$ \\
\hline \multirow[t]{2}{*}{ Jharkhand } & Oraon & 0.02 & 0 & 0.93 & 0.04 & 0.02 & 0 & $0.000^{*}$ & $0.003 *$ \\
\hline & Munda & 0.24 & 0 & 0.76 & 0 & 0 & 0 & 0.065 & 0.082 \\
\hline \multirow[t]{4}{*}{ Rajasthan } & Pateliya & 0.18 & 0 & 0.83 & 0 & 0 & 0 & $0.018 *$ & $0.039 *$ \\
\hline & Naikda & 0.14 & 0 & 0.86 & 0 & 0 & 0 & 0.503 & 0.373 \\
\hline & Damor & 0.10 & 0.04 & 0.84 & 0 & 0.02 & 0 & $0.000 *$ & $0.003 *$ \\
\hline & Kathodi & 0.13 & 0 & 0.84 & 0 & 0.01 & 0.014 & $0.043 *$ & 0.167 \\
\hline Andhra & Brahmin & 0.12 & 0.03 & 0.85 & 0 & 0 & 0 & $0.000 *$ & $0.002 *$ \\
\hline \multirow[t]{3}{*}{ Pradesh } & Kolam & 0.02 & 0 & 0.93 & 0.04 & 0.01 & 0 & 0.999 & 0.998 \\
\hline & Thoti & 0.14 & 0 & 0.86 & 0 & 0 & 0 & 0.598 & 0.618 \\
\hline & Nayakpod & 0.09 & 0 & 0.77 & 0.05 & 0.09 & 0 & $0.000 *$ & $0.003 *$ \\
\hline
\end{tabular}

* $P<0.05$ 
However, among the human population groups world-wide, the $4 \mathrm{R}$ allele is present with relatively higher frequency, consisting of only one particular form: $\alpha \beta \theta \zeta$ (Lichter et al., 1993); this hints at the possibility of this allele being of ancestral human origin. This hypothesis is further confirmed based on limited sequence data reported for primate $D R D 4$ 4R allele (Livak et al., 1995), the lower level of linkage disequilibrium (LD) for polymorphisms surrounding this allele, and the sequence motif arrangements of the non- $4 \mathrm{R}$ alleles (Ding et al., 2002).

The presence of the human ancestral $4 \mathrm{R}$ allele at significant frequencies in all Indian populations, irrespective of their tribe and caste status, supports the common genetic substratum of the Indian population proposed previously (Saraswathy et al., 2010). Moreover, the high frequency of progenitor 4R allele among the south Indian and east Indian populations belonging to Proto-Australoid ethnic elements and Dravidian and Austro-Asiatic speakers, respectively, is strongly supportive of the view that Proto-Austaloid groups were the earliest settlers in India and might have diversified into two groups in the course of human evolution in the region (Kumar et al., 2008). Furthermore, studies conducted on different population groups of eastern India (Bhaduri et al., 2007), and southern India (Ghosh and Seshadri, 2005) also found the $4 \mathrm{R}$ allele to be the most prevalent. However, they also reported very low frequencies of $8 R$ and $9 R$ alleles in some populations. In the present studied populations, long repeat alleles, i.e. 8-11R, are found to be absent.

In terms of distribution, the $7 \mathrm{R}$ allele stands next to the $4 \mathrm{R}$ allele in the majority of the world's populations. Moreover, available biochemical data indicate that both the $2 R$ and $7 R$ proteins have blunted responses to dopamine as compared to that of the 4R protein (Leung et al., 2005). Despite such similarity in their biochemical manifestation, the $2 \mathrm{R}$ and $7 \mathrm{R}$ alleles show remarkable differences in their distribution patterns among various world populations: the $2 \mathrm{R}$ allele is more abundant among south and east Asian populations, including Indian populations, while the $7 \mathrm{R}$ allele is more widely distributed among the New World populations.

In the Indian context the $2 \mathrm{R}$ allele is the second most common allele after the $4 \mathrm{R}$ allele. The $7 \mathrm{R}$ allele, which is the second most common allele in other world populations, is found to be the least frequent in Indian populations along with the $3 \mathrm{R}$ allele. The $7 \mathrm{R}$ allele is found at very low frequencies among the caste populations of northern, northeastern and north-western parts of India, which were the most vulnerable regions in terms of the inflow of genes from the northern part of the globe, specifically Europe, where $7 \mathrm{R}$ is found in relatively high frequencies, ranging from 0.06 to 0.27 (http://alfred.med.yale.edu/alfred/SiteTable1 A working.asp?siteuid=SI000224I). However, such high frequencies of $7 \mathrm{R}$ are also found in some population groups of Africa (http://alfred.med.yale.edu/alfred/SiteTable1A working.asp?siteuid=SI000224I). In contrast to this, all the tribes of India and all the caste groups of south India considered in the present study are found to evidence a complete absence of 7R allele.

Most of the presently studied populations, in spite of being from different geographical regions and belonging to different linguistic families, such as Indo-European (north-
western-Patelia, Naikda, Damor), Dravidian (southernKolam, Thoti, Nayakpod), Dravidian (east-Oraons), and Austro-Asiatic (east-Mundas), show absence of the 7R allele. All these populations, being tribal populations of India, are supposed to be the autochthones of the subcontinent.

Ding et al. (2002) proposed two possible hypotheses regarding the evolution of the $\mathrm{DRD} 4$ gene: (i) recent mutational origin of $7 \mathrm{R}$ allele from the $4 \mathrm{R}$ allele, subsequently followed by positive selection of the same; and (ii) importation of the $7 \mathrm{R}$ allele from a closely related Hominid, most probably Neandertals. As the proposed age of the 7R allele (30000-50000 years) coincides with the existence of Neandertals and the archaic type of Homo sapiens sapiens, they also related the $7 \mathrm{R}$ allele to major expansions, radical new technologies (Upper Palaeolithic) and the development of agriculture. Further, Wang et al. (2004) proposed that the recent origin of the $7 \mathrm{R}$ allele and its high frequencies in some world populations could be attributed to a strong positive selection. However, Naka et al. (2011) argued that DRD4 7R is not extraordinarily young, and as such is not subjected to positive selection, and proposed that the increase in its frequencies in some populations could be attributed to genetic drift.

However, one cannot rule out the possibility of the earlier presence of thr 7R allele in Indian populations as they possess high frequencies of the $2 \mathrm{R}$ allele, and this, according to Ding et al. (2002), is a derivative of $7 \mathrm{R}$ allele. But as the $2 \mathrm{R}$ allele is supposed to have come into existence after the $7 R$ allele, one cannot rule out the possibility that the populations of India had the 7R allele in the initial stages of their inhabitation of the Indian subcontinent, either by origin or by migration, and later there could have been a selective disadvantage of the $7 \mathrm{R}$ allele, as they opted for settled lifestyles as proposed by Chen et al. (1999). This hypothesis is to some extent supported by studies of Wang et al. (2004) who proposed that the $7 \mathrm{R}$ allele decreased after its migration into India. Furthermore, the presence of the $7 \mathrm{R}$ allele at negligible frequencies in some populations could possibly be because of recent gene flow from Eurasia where its frequency is reported to be high (Basu et al., 2003).

\section{Conclusion}

The presence of the $4 \mathrm{R}$ and $2 \mathrm{R}$ alleles in all the populations studied here at relatively high frequencies, and the presence of the 5R allele (Hominoid specific) in at least one population from each geographical region-i.e. Rajput and Brahmin from north India; Kabui, Meitei, Thadou, and Paite from north-east India; Oraon from east India; Kolam and Nayakpod from South India-suggests a common, primitive, autochthonous genetic substratum of India. Further, restriction of the 7R allele to a few north and north-east Indian populations indicates that the populations of these geographical regions have experienced a recent gene flow from the north, where the frequency of $7 \mathrm{R}$ is reported to be relatively high. Even though the present study results are based on a single gene, the highly polymorphic nature of the gene with repeat alleles ranging from $2 \mathrm{R}$ to $11 \mathrm{R}$ makes it a reliable marker for anthropological studies. However, more detailed studies, including the sequencing data of the repeat regions 
of DRD4 gene along with haplotype analysis, are likely to give additional insight into the peopling of India.

\section{Acknowledgments}

We are very thankful to all the peoples who participated in the present study for their kind cooperation. The authors wish to thank the Department of Biotechnology (DBT), the University Grants Commission (UGC) and the UGC Special Assistant Programme (SAP) for providing the financial assistance to carry out the present study.

\section{References}

Basu A., Mukherjee N., Roy S., Sengupta S., Banerjee S., Chakraborty M., Dey B., Roy M., Roy B., Bhattacharyya N.P., Roychoudhury S., and Majumder P.P. (2003) Ethnic India: a genomic view, with special reference to peopling and structure. Genome Research, 13: 2277-2290.

Benefit B.R. and McCrossin M.L. (1995) Miocene hominoids and hominid origins. Annual Review of Anthropology, 24: 237256

Bhaduri N., Das M., Das A.B., and Mukhopadhyay K. (2007) Dopamine receptor D4 exon 3 variable number of tandem repeat polymorphism: distribution in eastern Indian population. Indian Journal of Human Genetics, 13: 54-58.

Chang F-M., Kidd J.R., Livak K.J., Pakstis A.J., and Kidd K.K. (1996) The world-wide distribution of allele frequencies at the human dopamine D4 receptor locus. Human Genetics, 98: 91-101.

Chen C., Burton M., Greenberger E., and Dmitrieva J. (1999) Population migration and the variation of dopamine D4 receptor (DRD4) allele frequencies around the globe. Evolution and Human Behavior, 20: 309-324.

Comings D.E., Gonzalez N., Wu S., Gade R., Muhleman D., Saucier G., Johnson P., Verde R., Rosenthal R.J., Lesieur H.R., Rugle L.J., Miller W.B., and MacMurray J.P. (1999) Studies of the $48 \mathrm{bp}$ repeat polymorphism of the DRD4 gene in impulsive, compulsive, addictive behaviors: Tourette syndrome, ADHD, pathological gambling, and substance abuse. American Journal of Medical Genetics, 88: 358-368.

Ding Y-C., Chi H-C., Grady D.L., Morishima A., Kidd J.R., Kidd K.K., Flodman P., Spence M.A., Schuck S., Swanson J.M., Zhang Y.P., and Moyzis R.K. (2002) Evidence of positive selection acting at the human dopamine receptor D4 gene locus. Proceedings of the National Academy of Science, USA, 99: 309-314.

Eisenberg D.T.A., Campbell B., Peter B., Gray P.B., and Sorenson M.D. (2008) Dopamine receptor genetic polymorphisms and body composition in undernourished pastoralists: an exploration of nutrition indices among nomadic and recently settled Ariaal men of northern Kenya. BMC Evolutionary Biology, 8: $173-184$.

Eisenegger C., Knoch D., Ebstein R.P., Gianotti L.R.R., Sándor P.S., and Fehr E. (2010) Dopamine receptor D4 polymorphism predicts the effect of L-DOPA on gambling behavior. Biological Psychiatry, 67: 702-706.

Gelernter J., Kranzler H., Coccaro E., Siever L., New A., and Mulgrew C.L. (1997) D4 dopamine-receptor (DRD4) alleles and novelty seeking in substance-dependent, personalitydisorder, and control subjects. American Journal of Human Genetics, 61: 1144-1152.

Ghosh A. and Seshadri M. (2005) Indian ethnic population characterized by dopamine (D4) receptor VNTR polymorphism. Annals of Human Biology, 32: 574-584.

Grady D.L., Chi H-C., Ding Y-C., Smith M., Wang E., Schuck S., Flodman P., Spence M.A., Swanson J.M., and Moyzis R.K. (2003) High prevalence of rare dopamine receptor D4 alleles in children diagnosed with attention-deficit hyperactivity disorder. Molecular Psychiatry, 8: 536-545.

Guha B.S. (1944) Racial Elements of India. Oxford: Oxford University Press.

Inoue-Murayama M., Niimi Y., Takenaka O., and Murayama Y. 2000. Allelic variation of the dopamine receptor D4 gene polymorphic region in gibbons. Primates, 41: 383-392.

Jonsson E.G., Nöthen M.M., Gustavsson J.P., Neidt H., Brené S., Tylec A., Propping P., and Sedvall G.C. (1997) Lack of evidence for allelic association between personality traits and the dopamine D4 receptor gene polymorphisms. American Journal of Psychiatry, 154: 697-699.

Khurana S. and Seshadri M. (2003) Distribution of allele frequencies of one VNTR and two STR loci in five population groups of South India. Journal of Forensic Science, 48: 1187-1188.

Kumar S., Padmanabham P.B.S.V., Ravuri R.R., Uttaravalli K., Koneru P., Mukherjee P.A., Das B., Kotal M., Xaviour D., Saheb S.Y., and Rao V.R. (2008) The earliest settlers' antiquity and evolutionary history of Indian populations: evidence from M2 mtDNA lineage. BMC Evolutionary Biology, 8: 230.

LaHoste G.J., Swanson J.M., Wigal S.B., Glabe C., Wigal T., King N., and Kennedy J.L. (1996) Dopamine D4 receptor gene polymorphism is associated with attention deficit hyperactivity disorder. Molecular Psychiatry, 1: 128-131.

Leung P.W., Lee C.C., Hung S.F., Ho T.P., Tang C.P., Kwong S.L., Leung S.Y., Yuen S.T., Lieh-Mak F., Oosterlaan J., Grady D., Harxhi A., Ding Y.C., Chi H.C., Flodman P., Schuck S., Spence M.A., Moyzis R., and Swanson J. (2005) Dopamine receptor D4 (DRD4) gene in Han Chinese children with attention-deficit/hyperactivity disorder (ADHD): increased prevalence of the 2-repeat allele. American Journal of Medical Genetics B Neuropsychiatric Genetics, 133B: 5456.

Lichter J.B., Barr C.J., Kennedy J.L., Tol H.H.M.V., Kidd K.K., and Livak K.J. (1993) A hypervariable segment in the human dopamine receptor D4 (DRD4) gene. Human Molecular Genetics, 2: 767-773.

Livak K.J., Rogers J., and Lichter J.B. (1995) Variability of dopamine D4 receptor (DRD4) gene sequence within and among nonhuman primate species. Proceedings of the National Academy of Sciences, USA, 92: 427-431.

Malhotra A.K., Virkkunen M., Rooney W., Eggert M., Linnoila M., and Goldman D. (1996) The association between the dopamine D4 receptor (D4DR) 16 amino acid repeat polymorphism and novelty seeking. Molecular Psychiatry, 1: 388-391.

McGeary J. (2009) The DRD4 exon 3 VNTR polymorphism and addiction-related phenotypes: a review. Pharmacological Biochemical Behaviour, 93: 222-229.

Miller S.A., Dykes D.D., and Polesky H.F. (1988) A simple salting out procedure for extracting DNA from human nucleated cells. Nucleic Acids Research, 16: 215.

Naka I., Nishida N., and Ohashi J. (2011) No evidence for strong recent positive selection favoring the 7 repeat allele of VNTR in the DRD4 gene. PLoS One 6: e24410.

Pilbeam D. (1979) Recent finds and interpretations of Miocene Hominoids. Annual Review of Anthropology, 8: 333-352.

Ray L.A., Bryan A., MacKillop J., McGeary J., Hesterberg K., and Hutchison K.E. (2009) The dopamine D4 Receptor (DRD4) gene exon III polymorphism, problematic alcohol use and novelty seeking: direct and mediated genetic effects. Addiction Biology, 14: 238-244.

Ruvolo M. (1997) Genetic diversity in Hominoid primates. Annual Review of Anthropology, 26: 515-540.

Saraswathy K.N., Meitei S.Y., Gupta V., Murry B., Sachdeva M.P., and Ghosh P.K. (2010) Allelic and haplotypic structure at DRD2 locus among five North Indian caste populations. American Journal of Physical Anthropology, 141: 651-657.

Sullivan P.F., Fifield W.J., Kennedy M.A., Mulder R.T., Sellman 
J.D., and Joyce P.R. (1998) No association between novelty seeking and the type 4 dopamine receptor gene (DRD4) in two New Zealand samples. American Journal of Psychiatry, 155: 98-101.

Swanson J.M. and Moyzis R.K. (2003) High prevalence of rare dopamine receptor D4 alleles in children diagnosed with attention-deficit hyperactivity disorder. Molecular Psychiatry, 8: $536-545$.

Swanson J.M., Sunohara G.A., Kennedy J.L., Regino R., Fineberg E., Wigal T., Lerner M., Williams L., LaHoste G.J., and Wigal S. (1998) Association of the dopamine receptor D4 (DRD4) gene with a refined phenotype of attention deficit hyperactivity disorder (ADHD): a family-based approach.
Molecular Psychiatry, 3: 38-41.

Trinkaus E. (2005) Early modern human. Annual Review of Anthropology, 34: 207-230.

Wang E., Ding Y-C., Flodman P., Kidd J.R., Kidd K.K., Grady D.L., Ryder O.A., Spence M.A., Swanson J.M., and Moyzis R.K. (2004) The genetic architecture of selection at the human dopamine receptor D4 (DRD4) gene locus. American Journal of Human Genetics, 74: 931-944.

Yeh F.C. and Yang R. (1999) Popgene Version 1.31. Microsoft window based freeware for population genetic analysis. University of Alberta and Tim Boyle, Centre for International Forestry Research, Canada. 